\title{
Cytology of Genus Sporobolus R. Br. from North India (Punjab Plain)
}

\author{
S. S. Bir, Manju Sahni and C. P. Singh \\ Department of Botany, Punjabi University, Patiala-147 002, India
}

Accepted September 5, 1986

The genus Sporobolus R. Br. of tribe Sporoboleae in family Graminae consists of 150 species which are tropical and warm temperate in distribution (Airy Shaw 1973). Out of these, only 16 species are recorded from the Indian subcontinent (Bor 1960).

So far, chromosome numbers of 55 species have been recorded and these vary from $2 n=$ 12 to $2 n=126$ (see foot note to Table 1). From India, only 8 species have been studied (Mehra et al. 1968, Christopher and Abraham 1974, Mehra 1982, Christopher 1985), but taxa from different phytogeographic regions of the country have not been fully investigated so far. Therefore, as a part of our project of cytological studies on North Indian grasses and sedges, the present work was undertaken on the members of Sporobolus from Punjab plain from where only 6 species have been recorded (Sharma 1983 and the writers). Except for S. fertilis (Steud.) W. D. Clayton which is very rare in Punjab and could not be collected, all others have been presently chromosomally investigated.

\section{Materials and methods}

Details of localities from where the materials were colleted are available in Table 1. Meiosis in young floral buds was studied following usual acetocarmine technique. Pollen fertility was ascertained by Mark's (1954) method. In order to reveal the existing cytological variability, if any, in each case, intensive analysis was done not only of several individuals but also of several populations.

\section{Observations}

Information about chromosome numbers recorded, ploidy level of taxa and the pollen fertility is given in Table 1. All the investigated taxa have normal meiosis except in case of $S$. helvolus and $S$. indicts. Three species, namely, S. coromandelianus, S. helvolus and $S$. indicus show the presence of $18 \mathrm{II}$ at diakinesis and M-I and $18+18$ or $(18+18)+(18+18)$ chromosomes at A-I and A-II (Figs. 1, 2, 3 respecitvely). For $S$. diander and $S$. marginatus, two cytotypes each with $n=12$ (Fig. 4) and $n=18$ (Fig. 5) for the former and $n=9$ (Fig. 6) and $\mathrm{n}=18$ for the latter species are recorded (cf. Table 1 ).

In $S$. helvolus with $\mathrm{n}=18(4 \mathrm{x})$ phenomenon of cytomixis has been observed in $38.5 \%$ of observed pollen mother cells (PMCs) at different stages of meiosis. Actual passing of chromatin material is seen in $63.4 \%$ of the cytomictic cells (Fig. 7). As a result of transmigration of nuclear material PMCs with increased (not countable) and decreased $(n=8,10,14,15,16)$, chromosome numbers have been located (Figs. 8, 9, 10). Due to these abonrmalities, pollen fertility is reduced to $85.8 \%$. In S. indicus nearly $72.7 \%$ of the observed PMCs show the presence of laggards and bridges at A-I which leads to highly decreased pollen viability $(20.5 \%)$.

The tetraploid and hexaploid cytotypes of $S$. diander can be distinguished easily as the tetraploids are taller $(52-57 \mathrm{~cm})$ with bigger leaves $(12-17 \mathrm{~cm})$, large sized inflorescence $(23-$ 

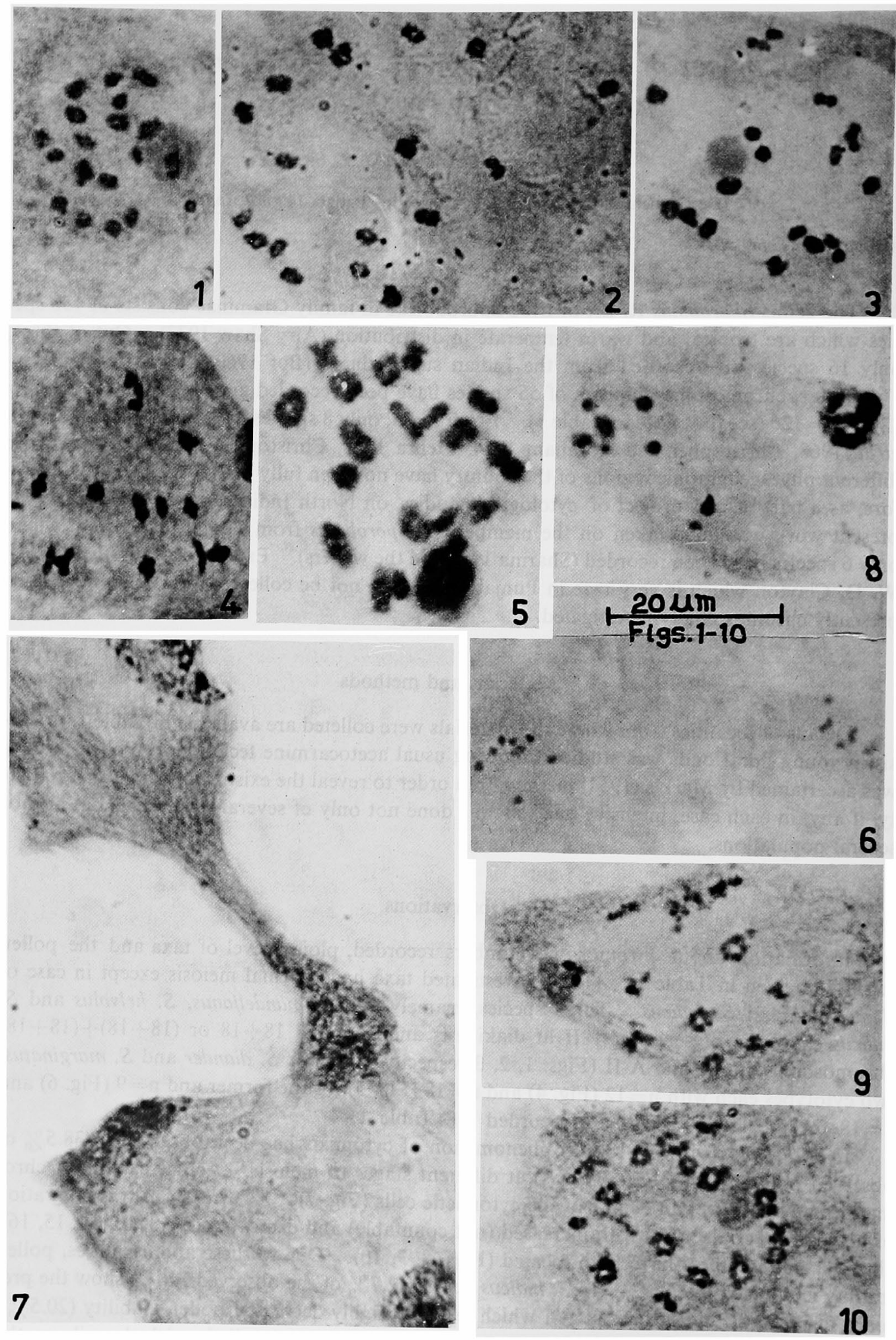
$26 \mathrm{~cm})$ and large sized pollen $(24 \times 20-23 \times 28 \mu \mathrm{m})$ as compared to hexaploid plants which are samller in size $(28-39 \mathrm{~cm})$, possess smaller leaves $(4.5-7.5 \mathrm{~cm})$ and inflorescence $(10-18 \mathrm{~cm})$. The pollen are nearly of the same size $(24 \times 20-28 \times 24 \mu \mathrm{m})$ as in case of tetraploids. It may be stated that both the cytotypes were growing under similar habitat conditions. However, in $S$. marginatus the tetraploid plants are more robust in appearance $(55-60 \mathrm{~cm})$ with bigger leaves $(9.5-11.5 \mathrm{~cm})$ and inflorescence $(10.5-11 \mathrm{~cm})$, but with small pollen $(24 \times 20-24 \times 24 \mu \mathrm{m})$ as compared to the diploid plants which are $30-32 \mathrm{~cm}$ tall, possess smaller $(7-10.5 \mathrm{~cm})$ sized leaves and $8.5-10.5 \mathrm{~cm}$ long inflorescence and comparatively bigger sized $(24 \times 24-28 \times 28 \mu \mathrm{m})$ pollen. Also pollen fertility is much reduced in tetraploids $(30-48 \%)$ as compared to the diploids $(98 \%)$.

\section{Discussion}

All the presently studied five species of Sporobolus are at polyploid level and are based on $\mathrm{x}=6(S$. diander) and $\mathrm{x}=9$ ( $S$. coromandelianus, $S$. helvolus, $S$. indicus and $S$. marginatus). Three well represented base numbers as $\mathrm{x}=9,10,12$ have been suggested (cf. Darlington and Wylie 1955, Fedorov 1969, Moore 1973) for the genus. Tateoka (1965) reported $\mathrm{n}=6$ in $S$. molleri from Uganda and another base number $\mathrm{x}=6$. Later on, Christopher (1985) on the basis of record of $\mathrm{n}=6$ for $S$. maderapatonous from South India supported the presence of $\mathrm{x}=$ 6. Now with the recording of $\mathrm{n}=12(4 \mathrm{x})$ and $\mathrm{n}=18(6 \mathrm{x})$ for $S$. diander from North India, the existence of $\mathrm{x}=6$ for Sporobolus is confirmed. This is a primary number for the genus and the other numbers $x=9,10$ have evolved through aneuploidy from $x=6$. The existence of $x=12$ is ruled out because the species supporting $n=12$ and considered diploid as based on 12, are now scored as tetraploid as based on $x=6$. Eventually, the genus Sporobolus is tribasic with $x=6,9$ and 10 .

On world-wide basis the cumulative cytological data* for 89 investigated taxa show that $83.03 \%$ are polyploids and the following species* show intraspecific cytotypes (both eu- and aneuploids): $S$. airoides $(2 \mathrm{n}=90,108,126), S$. asper $(2 \mathrm{n}=54,88,108), S$. berteroamus $(2 \mathrm{n}=$ $36,44), S$. capensis $(2 \mathrm{n}=18,36), S$. coromandelianus $(2 \mathrm{n}=24,36), S$. cryptandrus $(2 \mathrm{n}=18,36$, $38,72)$, S. cubensis $(2 \mathrm{n}=72,80,90)$, S. diander $(2 \mathrm{n}=24,36)$, S. fertilis $(2 \mathrm{n}=24,36,48)$, S. festivus $(2 \mathrm{n}=18,24,36,40-45,48,54), S$. marginatus $(2 \mathrm{n}=18,20,36), S$. piliferus $(2 \mathrm{n}=20,36), S$. pyramidalis $(2 \mathrm{n}=24,30,36), S$. pyramidatus $(2 \mathrm{n}=24,30,36,54), S$. stapfionus $(2 \mathrm{n}=24,36), S$. tenuissimus $(2 \mathrm{n}=12,40), S$. tremulus $(2 \mathrm{n}=20,48), S$. virginicus $(2 \mathrm{n}=18,20,23-30,30), S$. wallichii $(2 \mathrm{n}=24,40)$.

The cause for aneuploid numbers could be sought in the presence of cytomictic PMCs as recorded by us in $S$. helvolus for the first time in the genus Sporobolus as well as irregular divisions during sporogenesis as noticed in $S$. indicus. This ultimately leads to genetically imbalanced pollen and the resultant different biotypes which are easily perpetuated in nature through vegetative propagation so common in grasses.

It is very likely that cytomixis is prevalent in other species too, but this has not been noticed so far. The existence of polyploid cytotypes at intraspecific level, raises an important question as to the taxomomy of the concerned species. The taxonomic reflections of cytological differences well supported by morphological differences as brought out presently from $S$. diander

Figs. 1-10. 1, Sporobolus coromandelianus PMC at diakinesis showing 18II. 2, S. helvolus M-I with 18II. 3, S. indicus diakinesis with 18II. 4, S. diander M-I showing 12II. 5, S. diander diakinesis showing 18II. 6, S. marginatus A-I with 9:9 distribution of chromosomes. 7-10:S. helvolus. 7, PMCs showing cytomixis. 8,9,10, cells after cytomixis with aneuploid numbers $(8,6 \mathrm{II}+2 \mathrm{I} .9,12 \mathrm{II} .10,16 \mathrm{II})$

* Based on information given in references mentioned in foot note $\left(^{*}\right)$ to Table 1 and present observations. 


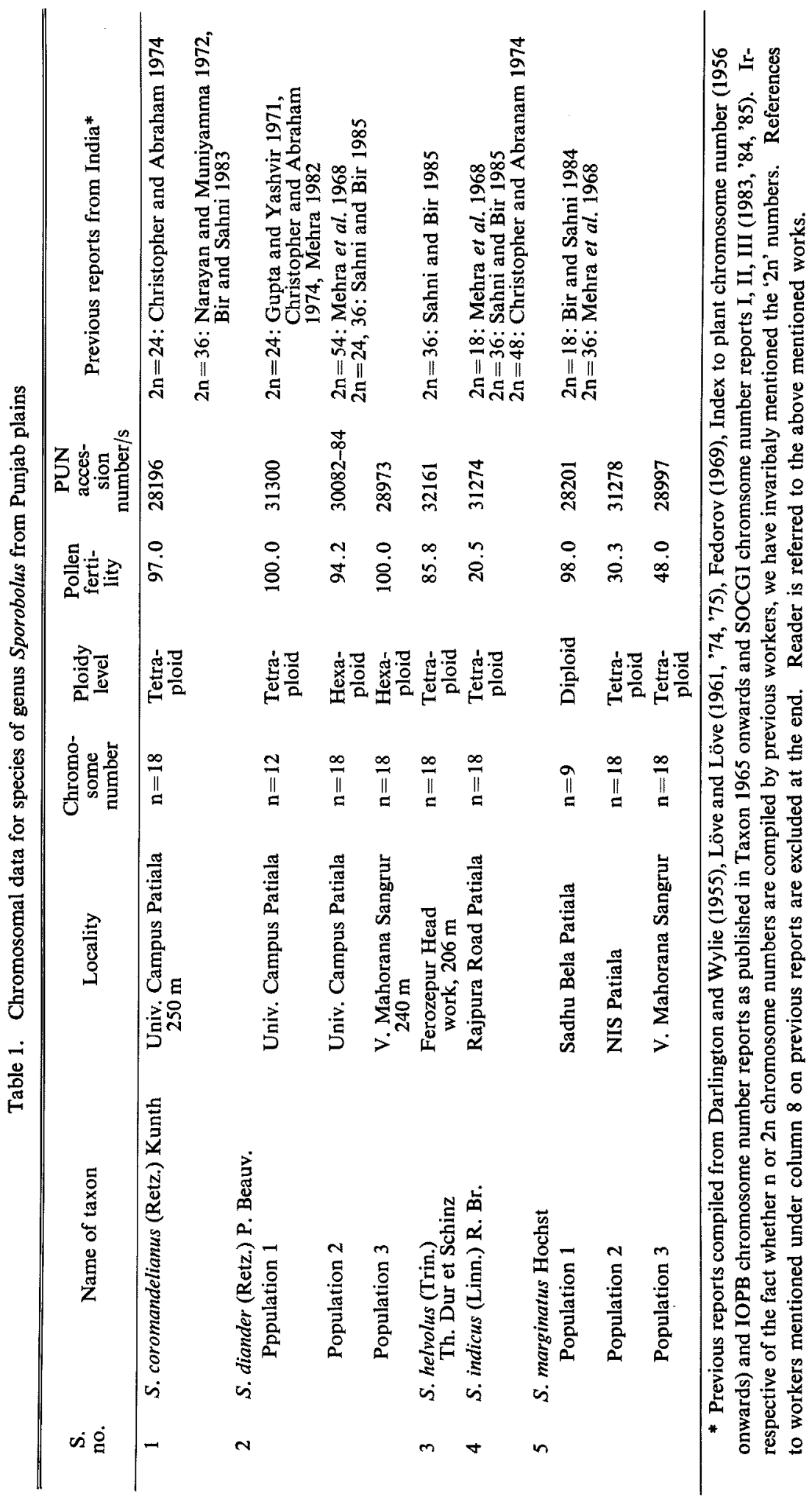


and $S$. marginatus, has to wait till comparisons with the type materials are made. In any case, there is an urgent need for the taxonomic revision of the genus Sporobolus.

\section{Summary}

As a result of chromosomal analysis of various populations of five species of genus Sporobolus it has been found that (i) morphologically distinct tetraploid $(\mathrm{n}=12)$ and hexaploid $(\mathrm{n}=$ 18) cytotypes for $S$. diander and diploid $(n=9)$ and tetraploid $(n=18)$ cytotypes for $S$. marginatus exist in nature, (ii) cytomixis leading to aneuploid numbers characterises $S$. helvolus and (iii) abnormal meiosis results in reduced pollen fertility in $S$. indicus.

All the five species are polyploids. On the basis of cumulative world wide data $83 \%$ of the species of genus Sporobolus are polyploids and intraspecific cytotypes exist in a large number of species. This calls for taxonomic revision of the genus in the light of cytomorphological evidence.

\section{Acknowledgements}

One of us (MS) is thankful to CSIR for financial assistance.

\section{References}

Airy Shaw, H. K. 1973. A Dictionary of Flowering Plants and Ferns. Univ. Press Cambridge (Revised 8th ed. of the late J. C. Willis).

Bir, S. S. and Sahni, M. 1983. In: SOCGI Chromosome Number Reports I. J. Cytol. Genet. 18: 56-63.

- and - 1984. In: SOCGI Chromosome Number Reports II. J. Cytol. Genet. 19: 111-117.

Bor, N. L. 1960. Grasses of Burma, Ceylon, India and Pakistan. Pergamen Press.

Christopher, J. 1985. Basic number six in Sporobolus from South India. Curr. Sci. 54(17): 880.

- and Abraham, A. 1974. Studies on the cytology and phylogeny of South Indian Grasses II. Sub-family Eragrostoideae. Cytologia 36: 561-571.

Darlington, C. D. and Wylie, A. P. 1955. Chromosome Atlas of Flowering Plants. London, George Allen Unwin Ltd.

Fedorov, An. A. (ed.) 1969. Chromosome Number of Flowering Plants. Kamarov Botanical Institute USSR, $926 \mathrm{pp}$.

Gupta, P. K. and Yashvir, 1971. In: IOPB Chromosome Number Reports XX. Taxon 18: 609-614.

Löve, A. and Löve, D. 1961. Chromosome Number of Central and North Western European Plant Species. Opera Botanica Alvquist \& Wiksolli Stockholm.

- and - 1974. Cytotaxonomical Atlas of the Slovenian Flora. J. Cramer F1 3301 Lehre.

- and - 1975. Cytotaxonomical Atlas of the Arctic Flora. J. Cramer F1 3301 Lehre.

Mark, G. E. 1954. An acetocarmine glycerol jelly for use in pollen fertility counts. St. Technology 29: 277.

Mehra, P. N. 1982. Cytology of East Indian Grasses. New Delhi.

-, Khosla, P. K., Kohli, B. L. and Koonar, J. S. 1968. Cytological studies in the North Indian Grasses. Res. Bull. Panjab Univ. 19: 157-230.

Moore, R. J. 1973. Index to Plant Chromosome Numbers 1967-1971. Edited by Moore, R. J. Netherlands.

Narayan, K. N. and Muniyamma, M. 1972. In: IOPB Chromosome number Reports XXXVIII. Taxon 21: 679-684.

Sahni, M. and Bir, S. S. 1985. In: SOCGI Chromosome Number Reports III. J. Cytol. Genet. 20: 204-207.

Sharma, M. L. 1983. Grasses of Punjab. Part II. Indian Forester 169(6): 495-508.

Tateoka, T. 1965. Chromosome numbers of some East African grasses. Amer. J. Bot. 52(8): 864-869. 